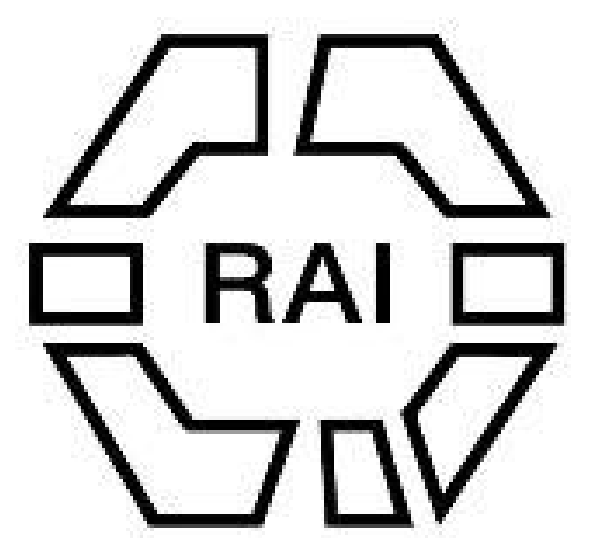

\title{
WILEY
}

\section{Sixteenth International Congress of Americanists.}

\section{Author(s): A. C. Breton}

Source: Man, Vol. 11 (1911), pp. 69-74

Published by: Royal Anthropological Institute of Great Britain and Ireland

Stable URL: http://www.jstor.org/stable/2839972

Accessed: 02-04-2016 06:25 UTC

\section{Your use of the JSTOR archive indicates your acceptance of the Terms \& Conditions of Use, available at}

http://about.jstor.org/terms

JSTOR is a not-for-profit service that helps scholars, researchers, and students discover, use, and build upon a wide range of content in a trusted digital archive. We use information technology and tools to increase productivity and facilitate new forms of scholarship. For more information about JSTOR, please contact support@jstor.org.

Royal Anthropological Institute of Great Britain and Ireland, Wiley are collaborating with JSTOR to digitize, preserve and extend access to Man 
friendly relations died, there would be, of course, the usual feast of pigs and the burial of the body.

3. After the burial the chief of the Kipkipto Society would approach the man who had charge of the burial and make arrangements for the purchase of the body. The only objections which were made were as to the price which was offered.

4. After a satisfactory agreement had been arrived at the Kipkipto Society would dig up the body during the night.

5. The body was left for a short time until decomposition was established, in order that the flesh might be more easily detached from the bones. After the flesh was removed the bones were all re-buried.

6. The body was not cooked, but was cut up into small pieces, minced, and mixed with many pungent and strong-tasting herbs, in order to counteract as much as possible the bad taste. The composition was then put into the small baskets usually carried by all the natives. These were slung over the shoulder and partly concealed under the armpit.

7. The composition was eaten secretly in the forest. Only those who were fully initiated were allowed to eat it.

8. It was very important that no part of it should be lost. So important was this that if a member could not restrain from vomiting he would make signs to his nearest companion, who would run to him and receive the ejected matter into his own mouth, for which service he would receive a small payment.

9. The members of the society were supposed to be possessed by spirits. They were said to become as light as air, so that they could sit on the smallest twigs. They were able to make themselves unseen. When walking they did not feel the ground, and were lunga - that is, mad.

10. The desire to eat this horrible mess was so strong that they would go for miles in order to purchase a corpse, and when opening a grave they would tremble with excitement.

11. The same customs were carried out when they obtained the body of an enemy which had been killed by them, or which had been purchased from an adjoining tribe, with the exception of the usual feast of pigs at the burial.

12. Mr. Pearson only knew of one society, and that is now broken up. The members of it were very much feared, and could go with impunity to places where an ordinary native would not dare to go.

13. The reasons given by the natives for this practice are that, by eating the bodies of their own people, they retain within the tribe the "strength, spirit, and influence" which they possessed, and by eating the bodies of their enemies who had previously killed one of their kindred they recovered the same qualities which had previously passed away from them. This, Mr. Pearson says, partly explains why a tribe will wait a whole generation (until their sons have grown up) for an opportunity to get even with the people who had previously conquered them.

G. BROWN.

\section{PROCEEDINGS OF SOCIETIES.}

\section{America: Archæology and Ethnography.}

\section{Sixteenth International Congress of Americanists.}

The report of the Sixteenth International Congress of Americanists, held

in Vienna in September 1908, was published early in 1910, and contains the fifty papers presented, as well as detailed accounts of the Congress proceedings, and of the subsequent tour through Hungary, Croatia, Bosnia, and the Herzegovina which gave so much pleasure to those members who took part in it. 
Dr. Franz Boas described in general terms the Results of the Jessup North Pacific Expedition, which cost Mr. Morris Jessup 100,000 dollars, including the publication of twelve volumes on the ethnology, philology, and anthropology of the regions visited. The main object was to study the connections between the cultures, speech, and races of the old and new world, and the place of the American aborigines amongst the races of the earth. An immense mass of material was collected by the twelve members, some of whom studied the isolated tribes of Eastern Siberia, whilst others went through the state of Washington and devoted much time to northern British Columbia. The New York Natural History Museum contains the magnificent collection brought back from the north-west coast.

The complex conditions observed showed the difficulty of the problems to be solved. It became evident that there had been intercommunication and migrations to and fro between north-west America and eastern Asia, and the vast experience of Dr. Boas in race-study has enabled him, in a measure, to judge what inferences may be drawn from the ascertained facts pending further investigation. It has become evident that the phonetic and morphological character of the isolated languages of north-east Asia cannot be separated from that of the American languages, and the confusing varieties of the latter (ten distinct languages being spoken between Behring's Straits and the Columbia river), may be gathered into a number of morphological groups which, in spite of great and even fundamental differences, may prove to have emerged from a single entity. In addition to considerations of language and anthropology, there is a striking resemblance in the legends of the peoples on both sides of the northern Pacific, and Dr. Boas gives reasons for thinking that there was an extremely ancient connection between them before the Eskimo had reached Behring's Straits, which began from the American side.

Sir Clement Markham's two papers are A Comparison of the Ancient Peruvian Carvings and the Stone Reliefs of Tiahuanaco and Chavin and Sarmiento's History of the Incas. The latter was published by Dr. Pietschmann of Göttingen in 1906, having been written about 1573. Sarmiento is the most reliable of the early Spanish writers on Peru, as his history was compiled from the carefully attested evidence of forty-two descendants of the Incas who were examined at Cuzco. From it we learn that the Inca system of government in its perfection, had only existed for three generations before the Spaniards came, and was a pure socialism which has never existed in the world before or since. All were well fed and well clothed, even amused, but there could be no freedom, no opening for ambition, no attempts to rise, and efforts at revolt met severe and cruel punishment.

In Dr. J. Kollmann's paper on Pygmies among the Aboriginal Races of America he gives illustrations of pre-Columbian pygmy skulls from Brazilian Guayana, from Guatemala, and from the coast cemeteries of Peru (Ancon and Pachacamac); the last excavated under the supervision of the Princess Therese of Bavaria. Her Royal Highness also brought away some bones, amongst them two femora, which denote statures of 1,161 and $1,463 \mathrm{~mm}$. Fourteen pygmy skulls from these graves have capacities between 1,000 and $1,190 \mathrm{~cm}$. In an urn from the caves of Maracà, northern Brazil, were found two pygmy skeletons. Judging from the femur, the heights of the bodies were 1,400 and $1,460 \mathrm{~mm}$., and the tibia show decided platycnemia. In none of these cases does there appear to have been disease to account for the small size. Dr. Kollmann does not mention the very small people to be seen in Yucatan, amongst whom a man of $5 \mathrm{ft} .4 \mathrm{in}$. looks quite tall and imposing.

Dr. Lehmann-Nitsche in Homo Sapiens and Homo Neogaus in the Argentine Pampas Formations gives his views on the remains of ancient man found there. In the Upper and Middle Loess they do not differ greatly from the modern Indian, and the bones of the extremities have the relative peculiarities of the inferior races. In 
the Lower Loess, which is geologically at least pliocene, was found the atlas of Monte Hermoso. In comparison with recent South American and other races this atlas shows very distinctive characters. It is too small for Homo primigenius, but belongs certainly to a very early form, approaching pithecanthropus. Reserving the name of Homo antiquus for the tertiary being, who may yet be found in the old world, the author has called the tertiary owner of this atlas Homo neogaus.

Dr. Capitan draws attention to the resemblances between certain objects from the old and new worlds, such as the flat rings of stone worn on the breasts by ancient Mexican gods and found in prehistoric France and in Japan. A statue of a bonze at the Musée Guimet has one on the left side of the breast. An interlaced sign, which expresses gold in Mexican picture-writings, appears on Merovingian buckles, and a development of it, seen in Central American reliefs, is known in China and Tibet as the intestine of Buddha.

A human femur with a series of deep incisions, used as a musical instrument in ancient Mexico and called omichicahuaztli, is paralleled by the deer horns similarly incised, of the quaternary period in France, and by instruments of the Hopi and Zuni.

Another interesting parallel is noted by Professor H. Matiegka, between North American incised and painted pottery and several groups of neolithic pottery in central Europe. He refers to Dr. Holmes' work, Aboriginal Pottery of the Eastern United States (twentieth annual report of the Bureau of Ethnology), and to many German writers on neolithic pottery. In both regions the sequence of style appears to be the same, and the resemblance is not only in the forms of the vessels, but in their whole decoration and ornaments (apart from some distinctive American and local Mediterranean motives), and their wide extension. The very early incised ware of northern Europe with the design filled with white is found in America, mostly in the northern area and in the Canadian kitchen-middens, which are of great antiquity. 'There are specimens with incised patterns as far as Costa Rica and Panama.

The whole question of the infinite resemblances between neolithic objects and implements of all kinds, as well as the pottery, in Europe and America, needs unprejudiced study.

In Recent Cave Work in America Dr. C. Peabody describes some caves in the Ozark Mountains. The rocks there are Silurian sandstone, Devono-carboniferous and sub-carboniferous, and in the first and third there are caves and rock-shelters which resemble those of the Dordogne. Examination of Jacob's Cavern, Benton County, Missouri, and Kelly Cavern, Madison County, Arkansas, showed that the deposits in them consisted of mud, fallen rock, and "ash." This last is a dark-coloured substance, very light in weight, certainly connected with the presence of man, and in quantity to length of occupancy, although an analysis proved unfavourable to the hypothesis that it is a true ash. Skeletons were in poor preservation, and usually incomplete, but where the inhumation is deep enough to have been undisturbed by animals, the types of burial known as "bundle" and "scissors" are found. The accompanying objects are insignificant. Animal bones belong only to recent species. The deposits are peculiarly rich in stone implements and fragments, and include hammer stones, polishing stones, and metates (grinding stones), knives, and projectile points, scrapers, and perforators. The pottery is rude and of simple design, but an industry of worked bone had developed, and bone implements, especially pins, are abundant. Textiles of wild cane are also found. The culture is noteworthy for what it lacks; there is no richlydecorated pottery, no intricately-carved shell, and the absence of ground celts and axes is almost absolute. Stalagmite $50 \mathrm{~cm}$, thick covers split bones, charcoal, and splintered flints in some places.

Dr. E. Seler has a learned paper, Latest Investigations of the Legends of Guetzacoatl and the Toltics, and a profusely illustrated description of the Ruins of Chich'en 
Itzá in Yucatan. Mr. A. P. Maudslay's great work will always be the necessary foundation for knowledge of the wonderful buildings and sculptures there, but quantities of reliefs and statues are not yet recorded, and Dr. Seler especially notices the caryatids, and the many figures in the frescoes and reliefs which are in an upholding position.

The sculptured stone table, supported by fifteen portrait statuettes, which stood between the two great serpent columns in the ante-chamber of the Temple of the Tigers (upper building), was discovered by Dr. Le Plongeon when he removed the mass of débris there. He buried the statuettes for their better preservation (after photographing the table in position), and they were found in 1902, and are now in Mexico city. Before they were, removed the present writer photographed and drew them in colour, for they had been harmoniously painted, as were the other sculptures, and Frau C. Seler also photographed them. The varied types of these portraits and the details of their costumes and feather mantles make them very remarkable.

Another small building had caryatid pillars, which supported a large stone with rows of Maya glyphs in sunk relief. The initial glyphs give a date corresponding to 3,993 years 224 days from the beginning-date of Maya reckoning.

Dr. C. V. Hartman gives interesting photographs of graves in Some Features of Costa Rica Archcoology. It is a great misfortune in that country that immense numbers of graves have been, and still are, ransacked for the gilt-copper objects found in them, whilst everything else is left or destroyed. Dr. Hartman studied limited areas on the Atlantic and Pacific coasts and on the high land. There were four main types of stone cists. One consisted entirely of slabs, both top, bottom, and sides ; another kind had walls of oval river-stones, and a pile of them as roof. A third form, on the Atlantic coast, was twice as deep and large, with roof of very large heavy slabs. The fourth form was in the mountains west of Cartago, where square-cut pieces of stone, the size of bricks, were used for walls, whilst roof and floor were of larger flat slabs. On account of the moist climate, nearly all objects of perishable materials, such as textiles, wood, bone, shell, \&c., have disappeared, and only those of stone, clay, and metal are left. Very beautiful painted pots are found in some graves. Dr. Hartman's published works give a good idea of the archæological riches of Costa Rica.

But in truth the profusion of antiquities in America is amazing, as shown by Professor Marshall Saville's Archaological Researches on the Coast of Esmeraldas, Ecuador. Thanks to information received from a resident, Mr. Stapleton, Professor Saville headed expeditions (financed by Mr. G. Heye) in 1906 and 1907 to the province of Manabi, and has published two fine volumes describing his discoveries. It is only regrettable that the object of the expeditions is mainly to collect rather than to make systematic excavations.

In 1908 he was again in Manabi for a short time before proceeding to Esmeraldas, and, in the low hill region south-west of Manta, he discovered near La Roma about forty bottle-shaped hollows, probably the tombs described by Cieza de Leon, somewhat like the Chultunes of Yucatan. These in Ecuador are cut in the solid rock, in places where they would not have been used for storing water, and average eight to ten feet in depth. They are symmetrically shaped, resembling enormous carafes, with an opening or neck two feet in diameter, and have smooth sides and rounded bottoms with a diameter equal to the depth. They were sealed by a circular stone slightly over two feet across and about two inches thick. Where the earth is of some depth before reaching the bed rock, courses of squared stones line the necks. The excavation of one pit produced fragments of human and animal bones, potsherds, and a stone ear plug. Similar graves honeycomb the ground in parts of Cajamarquilla, an ancient ruined city near Lima, Peru.

In the province of Esmeraldas there was a different mode of burial; in great pottery tubes. One found at Tonchigue, two and a half feet high with a diameter of 
twenty inches, was resting on, as well as covered by, a jar. It contained a skeleton and a number of gold and copper objects. So many of these tubes were found (usually considerably below low-tide mark) near the village of Atacames, that almost every house has one or more, used for storage purposes. Tubes of this character are found from La 'Tolita south, nearly to the border of the province of Manabi. Atacames was the chief town of an ancient province, and in the river bank enormous deposits of pottery and shells are oxposed. Skulls found there have tiny gold discs set in the teeth.

At La Tolita, on an island called Tola, at the mouth of the Santiago river, seventy-five miles north of the town of Esmeraldas, there are forty mounds in a cleared portion of the forest. A trench was dug through the largest mound and at a depth of 7 metres a skeleton was found in sitting position, holding a large clay seal or stamp in its hand. With it were a number of pottery vessels, a gold egg with an emerald in it, and other interesting objects. In the level parts of the island, wherever excavations are made, gold is found by placer washing, and there are thousands of fragments of painted pottery, vessels, and figures (frequently broken by the workmen's picks) to a depth of five feet in the mud and decayed vegetable deposit. A collection of 2,000 pieces of worked gold was obtained, of an infinite variety of forms. The greater part of the jewels are of very diminutive size, and a lens must be used in order to study the workmanship. Amongst them are gold rings and pendants set with stones, minute filigree masks, nose, ear, and lip ornaments, and nails of various forms, which were set in holes in the face, as described by the early Spaniards. There are also gold fish-hooks, needles, and awls. Some jewels are of pure platinum, or of platinum and gold filigree. These minute objects show the marvellous skill of the ancient workers, and they are found in extraordinary profusion in the alluvium near the mouths of all the streams which flow into the Pacific within a certain limit. The great deposits of pottery appear to have been scattered, redistributed, and alluvium formed over them, a process repeated in three different periods, at one place at least.

Dr. Max Uhle's opportunities of studying the Primitive Culture in the Neighbourhood of Lima, in the course of the excavations made by him for the Universities of Pennsylvania and California, and for the splendid museum he has created in Lima, have enabled him to formulate a provisional sequence for his finds, with the knowledge also obtained by his researches at the ruins near Trujillo.

$\mathrm{He}$ discovered at Ancon a very early site of primitive fisherfolk, from whom the people may have descended who left the huge extent of mounds 30 or 40 feet high, spread over the plain there, and known as the Necropolis of Ancon, although really a series of dwellings and shell heaps in which interments have been made. At Pachacamac his excavations proved the super-position of temples and buildings with their respective burials, pottery, \&c. At Nieveria he found an ancient cemetery with a very great variety of artistic objects of bone, shell, wood, and mosaic, in addition to pottery of the most decorative kind. From Chancay also he obtained fine painted pottery, and all this is different from the later well-known Peruvian type. It belongs to the Ica-Nazca region farther south, where Dr. Uhle, after long search, found great numbers of beautiful pots covered with mythological paintings.

Tentative excavation in the enormous mounds built of small bricks near Lima, resulted in the finding of burial urns of unusual size and thickness. It is most unfortunate that, owing to want of money, the Peruvian Government has been unable for the last two years to pay for the further exploration which Dr. Uhle is so capable of managing, as shown by the great collections he has brought together in a short time. Irresponsible persons dig everywhere, and sell their finds to foreigners, to the infinite loss of science. 
In his paper on The Significance of the Intihuatana Dr. Uhle brings together photographs of the different gnomons which he discovered on the hillsides round Cuzco, as well as the one called Intihuatana at Pisac, the only sun temple left in good condition.

Amongst the philological contributions Father Morice's sprightly French description of The Verb in the Déné Languages will delight the reader. Far from being a dry dissertation, it gives a vivid picture of the extraordinary richness and variety of terms which the Indian mind has found necessary to express its subtle distinctions of thought. Déné possesses, for every French verb, thousands of synonyms with distinct shades of meaning, and the total number of its verb expressions can be counted by millions.

One category of verbs has seventeen persons for each tense, whilst certain verbs of locomotion have twenty-one. For instance, "to start forth" has not only the usual six persons to each tense, but can express two persons, one of two persons, one of several, and so on, in each case changing the word used. Then there are the objective verbs whose elements change with the nature of the object which they have as complement. In pp. 587-9 the author gives the verbs developed from "to put," forming over 23,000 in one series only, owing to the great number of variations possible, for here the verbs take on the character of particles of numeration, according to the class of object referred to.

"The verbs of locomotion also offer a vast horizon of possibilities. The Déné " changes his verb for 'to progress' according as he goes on foot, or in a vehicle, " by canoe, sledge, or on horseback, with difficulty in a crowd, or sailing over the " great areas of his lakes, with care as one who has tender feet, or running, with " crutches or leaping, whilst he is cutting with the axe or a knife, gathering fruit " or dancing, \&c. The movements of the stars, the air, fog, heat, a canoe, a path " considered as leading to a place, and many other things, are also expressed by " special verbs.

"Adjective verbs are conjugated regularly and from them are derived a long " series of comparative verb forms. Substantive verbs likewise are true verbs with " a complete conjugation, but are often impersonal."

Dr. F. Heger, in addition to his heavy work as secretary-general, prepared a special catalogue of the American collections in the Imperial Natural History Museum, and gave a short paper, mentioning the chief treasures. These are an ancient feather shield, the centre of a wooden shield with turquoise mosaic, a large feather fan, an animal's head in mosaic, and the magnificent feather headdress in the shape of a mythical sun-bird, which was also the subject of a monograph. Dr. Heger paid a tribute to Johann Natterer, a zoologist who was in Brazil from 1817-1835, and brought back to Vienna great ethnological collections "with far-seeing enthusiasm " at a time when the science had not even a name."

Space fails to do justice to many other papers of interest, such as that by Dr. Thalbitzer on the Heathen Priests of Greenland, Dr. Preuss on the ceremonial Festival of the Cora Indians of Western Mexico, amongst whom he lived from 1905 to 1907, the Comte de Charency's on the Numeration of the Tzotzil Language, and that by Lic. Belmar, in which he traces a connection between the Tarasco and the Languages of the Mixteco-Zapoteca-Otomi Family.

Anongst the forty works presented to the Congress were the Reisestudien aus dem Westlichen Sudamerika by Princess Therese of Bavaria, von Weiser's valuable edition of early American maps, known as the Islario de Alonso de Santa Cruz and Señor Batres' Prehistoric Civilization along the Papaloapam River.

A. C. BRETON. 